\title{
POST-SURGICAL COMPLICATIONS IN PATIENTS WITH CERVICAL SPONDYLOTIC MYELOPATHY
}

\author{
COMPLICAÇÕES PÓS-CIRÚRGICAS EM PACIENTES COM MIELOPATIA ESPONDILÓTICA CERVICAL \\ COMPLICACIONES POSQUIRÚRGICAS EN PACIENTES CON MIELOPATÍA \\ ESPONDILÓTICA CERVICAL
}

Luis Mario Altamirano Gutiérrez', Ulises loreto Nava1', Rubén Torres Gonzálezi', Iván Ramsés Águila Ledesma1, Erika Vanessa Tapia Flores ${ }^{1}$, René Morales de los Santos ${ }^{1}$, José Manuel Pérez Atanasio ${ }^{1}$, Eulalio Elizalde Martínez

1. Advanced Specialty Medical Unit (UMAE) “Dr. Victorio De la Fuente Narváez”, Ciudad de México.

\begin{abstract}
Objective: To identify the incidence and type of postoperative hospital complications in patients with cervical spondylotic myelopathy (CSM) treated by anterior approach, and to describe comorbidities present in patients who had complications. Methods: Retrospective, observational, descriptive cohort study of secondary sources (medical records), over a period of 3 years. We included 180 cases treated by anterior approach, excluding revision surgeries. Results: There was an incidence of complications of $11.11 \%$ (20 cases), with no statistically significant difference between sexes. The main complication was pneumonia (50\%), associated to prolonged intubation (40\%), followed by neurological impairment (20\%). In the hospital outcome he was found most often to another hospital discharge (65\%, 13 cases). The main comorbidity was systemic arterial hypertension (31.58\%, $p=0.46)$, followed by smoking $(26.32 \%, p$. 10$)$. Conclusions: The highest hospital incidence of postoperative complications was found in patients with CSM treated by anterior approach in relation to that reported in the literature. There was a high incidence of airway complications not correlated with soft tissue edema or hematoma in more than half of the cases. The incidence of airway complications shows an area of opportunity to improve extubation protocols and management of the airways in post-surgical special care unit. Level of Evidence III. SIRELCIS Registry: R-2014-3401-5. Study conducted without commercial support.
\end{abstract}

Keywords: Spinal cord diseases; Multiple trauma; Postoperative period.

\section{RESUMO}

Objetivo: Identificar a incidência e o tipo de complicações pós-operatórias hospitalares em pacientes com mielopatia espondilótica cervical (MEC) tratados por acesso anterior e descrever as comorbidades presentes em pacientes que tiveram complicações. Métodos: Estudo de coorte, retrospectivo, observacional, e descritivo de fontes secundárias (prontuários médicos), em um período de três anos. Foram incluídos 180 casos tratados por acesso anterior, excluindo cirurgias de revisão. Resultados: Verificou-se incidência de complicações de $11,11 \%$ (20 casos), sem diferença estatisticamente significativa entre sexos. A principal complicação foi pneumonia (50\%), associada à intubação prolongada (40\%), seguida de comprometimento neurológico (20\%). No momento da alta, ele foi encontrado na maioria das vezes para outra alta hospitalar (65\% dos casos). A principal comorbidade presente foi hipertensão arterial sistêmica (31,58\%, $p=0,46)$, seguida por tabagismo $(26,32 \%, p$ 0,10). Conclusões: A maior incidência hospitalar de complicações pós-operatórias foi encontrada em pacientes com MEC tratados por acesso anterior com relação ao relatado na literatura. Constatou-se alta incidência de complicações nas vias aéreas não correlacionadas a edema de tecidos moles ou hematoma em mais da metade dos casos. A incidência de complicações nas vias respiratórias mostra uma área de oportunidade para melhorar os protocolos de extubação e manejo das vias aéreas na unidade de cuidados especiais pós-cirúrgicos. Nível de evidência III. Registro SIRELCIS: R-2014-3401-5. Estudo realizado sem apoio comercial.

Descritores: Doenças da medula espinal; Traumatismo múltiplo; Período pós-operatório.

\section{RESUMEN}

Objetivo: Identificar la incidencia y el tipo de complicaciones posquirúrgicas intrahospitalarias en pacientes con mielopatía espondilótica cenvical (MEC) tratados por vía anterior y describir las comorbilidades presentes en los pacientes que desarrollaron complicaciones. Métodos: Estudio de cohorte retrospectivo, observacional, descriptivo de fuentes secundarias (expediente clínico), en un período de 3 años. Se incluyeron 180 casos de MEC tratados por vía anterior, excluyendo cirugías de revisión. Resultados: Se encontró una incidencia de complicaciones del 11,11\% (20 casos), sin diferencia estadísticamente significativa entre sexos. La principal complicación fue neumonía (50\%), asociada en 40\% a intubación prolongada, seguida por deterioro neurológico (20\%). En el desenlace hospitalario se encontró con mayor frecuencia el egreso a otro hospital (65\% de los casos complicados). La principal comorbilidad presente fue la hipertensión arterial sistémica (31,58\%, $p=0,46)$, seguida por tabaquismo (26,32\%, p 0,10). Conclusiones: Se encontró mayor incidencia de complicaciones posquirúrgicas intrahospitalarias en pacientes con MEC tratados por vía anterior, en relación con lo reportado en la literatura. Se encontró incidencia elevada de complicaciones de vías aéreas, sin relación con edema de partes blandas o hematoma en más de la mitad de los casos. La incidencia de complicaciones de vías respiratorias muestra un área de oportunidad para la mejora de los protocolos de extubación y manejo de vías respiratorias en la unidad de cuidados especiales posquirúrgicos. Nivel de evidencia III. Registro SIRELCIS: R-2014-3401-5. Estudio realizado sin apoyo comercial.

Descriptores: Enfermedades de la médula espinal; Traumatismo múltiple; Período posoperatorio.

Study conducted at the Advanced Specialty Medical Unit (UMAE) “Dr. Victorio De la Fuente Narváez", Clinical Department of Spine Surgery, Ciudad de México.

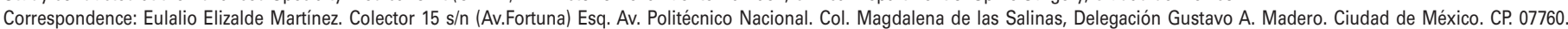
eulalio.elizalde@imss.gob.mx, doctorelizalde@gmail.com 


\section{INTRODUCTION}

Cervical spondylotic myelopathy (CSM) is the most common spinal cord disorder in people over 55 years of age. ${ }^{1-3}$ Anterior approach decompression and fusion are indicated in a large number of cases with an anterior compressive component and kyphotic deformity. ${ }^{4-11}$ Robinson and Smith were the first to describe this surgical approach in $1955 .^{9,12}$

The anterior approach is considered a reliable and effective treatment method for CSM, ${ }^{5}$ however, it is associated with potential complications: neurological deterioration, recurring paralysis of the laryngeal nerve, esophageal perforation, and respiratory complications. The latter is one of the most serious adverse events. The worldwide incidence of complications from anterior approach cervical surgery varies, having been reported as up to $6.1 \%$ by Sagi et al., ${ }^{10}$ with $1.9 \%$ requiring reintubation. A review of 4,589 cases by the Sociedad de Investigación de Columna Cervical [Society for Cervical Spine Research] showed a total of 5.3\% with complications. ${ }^{10}$ In terms of the incidence of the formation of hematomas, reports vary between 0.2 and $1.9 \%{ }^{13,14}$ One of the most serious and potentially fatal adverse events is the compromise of the airway secondary to the formation of a hematoma in the immediate postoperative period, causing obstruction of the upper airway. ${ }^{13-14}$ To date there are no level 1, 2, or 3 studies that discuss airway complications. The protocols are based on level 4 and 5 studies and derived from reports of retrospective case series and the opinions of specialists. ${ }^{10,13,14}$

As a consequence of the inversion of the population pyramid, over the last 10 years an increasing number of cases of CSM have been registered at the Clinical Department of Orthopedic Spine Surgery of the UMAE, more than $65 \%$ of whom were managed by anterior approach. The objective of this study was to identify the incidence and the type of postoperative in-hospital complications in patients with CSM treated by anterior approach and to describe the comorbidities in those patients with complications.

\section{METHODS}

A retrospective, observational, descriptive cohort study was conducted. Secondary sources, consisting of the hard copy and electronic clinical records of patients diagnosed with CSM who had undergone anterior approach surgery at the Clinical Department of Orthopedic Spine Surgery of the UMAE "Dr. Victorio de la Fuente Narváez" I.M.S.S, covering a three-year period (January 2011 to December 2013) were used. Male and female patients older than 18 years of age with complete registration data including sex, age, weight, height, comorbidities, type of surgical procedure, complications, and in-hospital outcome were included. Patients with incomplete registration data and previous revision surgery were excluded.

The sample size was calculated using the Hulley tables. For our descriptive study with dichotomous variables, with a confidence level of $95 \%$, an interval amplitude of 0.20 , a power of $80 \%$, and an expected ratio of 0.05 (incidence of complications of $5.3 \%$ ), the result was 88 patients. Adjusting by $20 \%$ to account for probable losses resulted in a total of 105 patients. ${ }^{13,14}$

We obtained 180 cases of CSM treated via anterior approach. The SPSS $₫$ version 17 program was used to analyze the results.

Because this was a risk-free type 1 investigation with data obtained from a secondary source (case files) without patient identification and without any changes to the natural history of the disease, no informed consent form was required. The study was reviewed and approved by the Institutional Review Board as complying with the basic principles of bioethics and was assigned SIRELCIS (Health Research Coordination Electronic Registration System) Registration number IMSS: R-2014-3401-5. Level of evidence III. The study was conducted without commercial support.

\section{RESULTS}

A total of 180 cases of patients with CSM who underwent anterior approach surgery and satisfied the inclusion criteria were obtained. Three cases were excluded because of previous cervical surgery and a total of 20 cases were eliminated because of incomplete registration of the variables to be analyzed. Of the 180 patients included in the study, 128 were men and 52 were women (72 and 29\%, respectively). Their ages ranged from 31 to 88 years of age, with a greater incidence between 61 and 70 years of age (43.89\%). A total of 129 patients presented comorbidities (71.67\%), the main ones being systemic arterial hypertension (SAH) in 94 patients (52.22\%) and tobacco use in 61 patients (33.89\%), followed by diabetes mellitus type 2 (DM2) in 32 patients (17.78\%), obesity in 24 patients (13.33\%), chronic obstructive pulmonary disease (COPD) in 11 patients (6.11\%), and cardiopathy in four patients $(2.22 \%)$.

Table 1 shows the distribution of patients according to age group, with the highest frequency in the 61 to 70 years of age group (43.89\%), followed by the 71 to 80 years of age group (27.78\%), reflecting that $71.67 \%$ of the population studied was found in these two groups.

There were a total of 20 patients with complications during the period analyzed (11.11\% of the total population studied), 15 of them male and 5 of them female, i.e., 75 and $25 \%$, respectively, with a p-value of 0.88 (non-significant).

The age ranges with the highest frequency of complications were the $61-70$ and $71-80$ years of age groups with 6 and 9 patients $(30 \%$ and $45 \%$, respectively), followed by the $51-60$ and $81-90$ years of age groups with 3 and 2 patients (15 and 10\%, respectively), finding a $p$-value of 0.09 for patients older than 70 years of age. (Figure 1)

Table 1. Distribution of patients by age group.

\begin{tabular}{c|c|c|c|c}
\hline \multicolumn{5}{c}{$\begin{array}{r}\text { Distribution of the patients studied } \\
\text { according to the age group }\end{array}$} \\
\hline Age range & Frequency & Percentage & $\begin{array}{c}\text { Valid } \\
\text { percentage }\end{array}$ & $\begin{array}{c}\text { Cumulative } \\
\text { percentage }\end{array}$ \\
\hline $30-40$ & 5 & 2.78 & 2.78 & 2.78 \\
\hline $41-50$ & 8 & 4.44 & 4.44 & 7.22 \\
\hline $51-60$ & 31 & 17.22 & 17.22 & 24.44 \\
\hline $61-70$ & 79 & 43.89 & 43.89 & 68.33 \\
\hline $71-80$ & 50 & 27.78 & 27.78 & 96.11 \\
\hline $81-90$ & 7 & 3.89 & 3.89 & 100 \\
\hline Total & 180 & 100 & 100 & \\
\hline
\end{tabular}

\section{Age ranges of the total number of patients with complications}

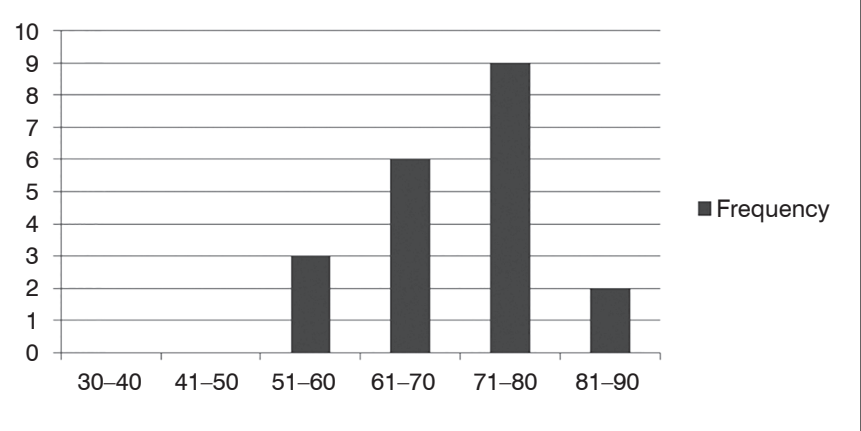

Figure 1. Frequency of complications by age range. 
The main comorbidity observed was pneumonia, present in 10 of the 20 patients with complications $(31.58 \%)$ with a p-value of 0.46 , followed by tobacco use in 10 patients $(26.32 \%)$ with a p-value of $0.10, \mathrm{DM} 2$ and obesity in 5 patients each $(13.16 \%)$ with a p-value of 0.10 , and finally, COPD and cardiopathy with 4 and 2 patients (10.53 and $5.26 \%$, respectively.

The principal complication observed was pneumonia, present in 10 of the 20 patients with complications (50\%), followed by neurological complications in five patients $(20 \%)$, cervical hematoma in four patients (16\%), dysphagia in 3 patients (12\%), and finally, one patient each (4\%) with dysphonia, esophageal perforation, and isolated respiratory failure. It should be noted that two or more complications were observed in some of the cases. The presence of postoperative cervical hematoma was associated with the development of anoxic ischemic encephalopathy in two cases and in one of them with the development of pneumonia. On the other hand, pneumonia was associated with the development of anoxic ischemic encephalopathy in one of the cases. All these complications were secondary to respiratory failure caused by obstruction of the airway. Only two of the complications were directly associated with the surgical technique, one of quadriplegia and one of esophageal perforation. (Figure 2)

Regarding the in-hospital outcomes of the patients with complications, the most frequently encountered situation was discharge to another hospital in 13 of the cases $(65 \%)$, followed by four cases (20\%) who were sent home, and three (15\%) who died. Discharge to another hospital was for the continuation of follow-up of the complications in all cases. One of the deaths was due to an acute myocardial infarction of unspecified origin, another to transoperative post-hemorrhagic hypovolemic shock, and the third from pneumonia associated with postoperative cervical hematoma, with a mortality rate of $1.66 \%$.

We found a statistically significant association with a p-value of 0.034 in which we observed an increase in the probability of postoperative complications in patients who had two or more comorbidities.

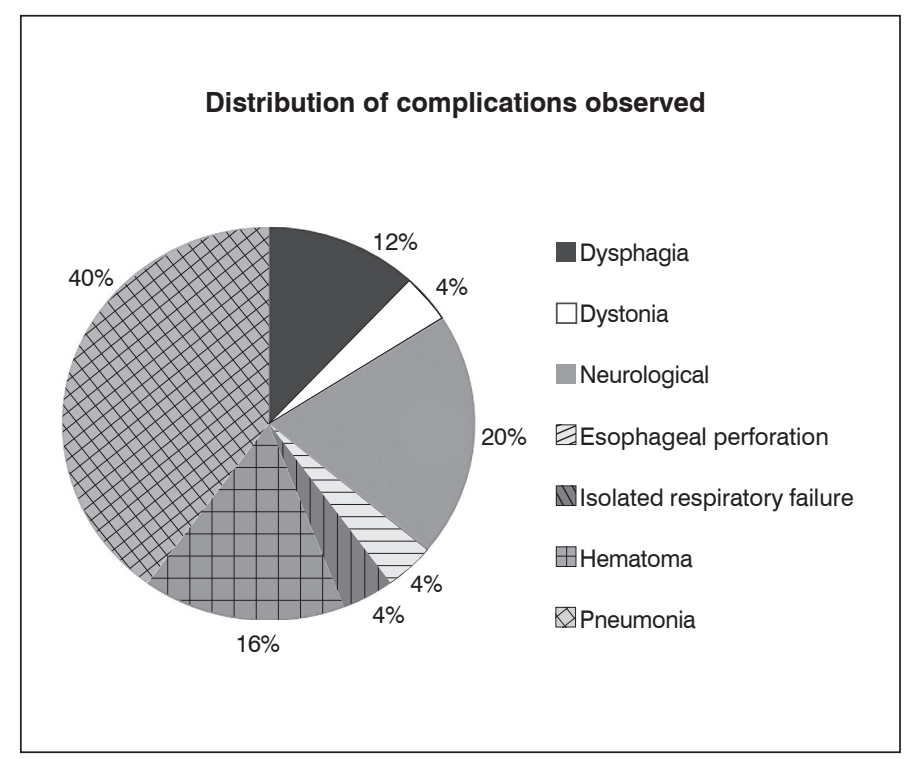

Figure 2. Frequency of complications observed.

\section{DISCUSSION}

There is little information reported about the impact of orthopedic spine pathologies in the population of our country, information that could be used to design prevention proposals and different therapeutic approaches for the timely detection of the possible demographic aspects and risk factors that can be associated with the development of postoperative complications that can be presented by patients with CSM who undergo anterior approach surgery.

A review of 4,589 cases in the database of the Sociedad de Investigación de Columna Cervical ${ }^{10}$ revealed a complication rate of $5.3 \%$, in contrast to that found in our study where the incidence was $11.11 \%$. As for the demographic aspects, Boakye et al. ${ }^{15}$ found the following: $51 \%$ of the patients were in the $45-64$ years of age range, the population was predominantly male at $58.1 \%$, and $62.73 \%$ of the patients had comorbidities, as compared to our study where the most frequently found age was between 71 and 80 years of age $(45 \%)$, predominantly male $(75 \%)$, and with comorbidities in $90 \%$ of the cases.

The major comorbidities reported by Boakye et al. ${ }^{15}$ were SAH in $34.2 \%$, followed by lung diseases in $12.8 \%$, and diabetes in $10.5 \%$, which is very similar to our findings, with SAH present in 60\%, diabetes in $25 \%$, and lung diseases in $20 \%$.

As regards the complications observed in our study, we found that acute respiratory failure was the most frequent, due to other complications such as respiratory tract infections (50\%) and cervical hematoma (20\%). This agrees with the complications mentioned in the international literature, ${ }^{10,13-15}$ as well as with those reported by the Hospital General de México ${ }^{16}$ where dysphagia and acute postoperative respiratory failure are among the most frequently observed complications. In our study there were no patients with infection of the surgical site. Jae-Sung et al. ${ }^{17}$ reported that the mortality rate decreased $0.57 \%$ to $0.26 \%$ between 1998 and 2003 . Boakye et al. ${ }^{15}$ found an in-hospital mortality rate of $0.57 \%$, in contrast to our study where the mortality rate during the study period from January 2011 to December 2013 was $1.66 \%$ of the total cases studied.

The in-hospital outcomes as reported by Boakye et al. ${ }^{15}$ were $0.57 \%$ death, $16.5 \%$ discharge to another hospital, and the rest returned to their homes without complications. We, on the other hand, found that of the total number of patients with complications, $15 \%$ died, $65 \%$ were discharged to another hospital, and 20\% returned home without complications.

The difference between the complications and the mortality rate of our case series as compared to those reported in the international medical literature may reflect the fact that many of our patients seek medical assistance in advanced stages of the disease with more than one comorbidity.

\section{CONCLUSIONS}

A greater incidence of postoperative in-hospital complications was found in patients with CSM treated by anterior approach than that reported in the literature. The results from this study indicated that the group the highest risk of complications was the males, older than 60 years of age, smokers, with systemic arterial hypertension, though this was not statistically significant. Only the association between two or more comorbidities with a possible increase in postoperative complications could be demonstrated.

We found a high incidence of complications of the airways without any direct relationship to hematoma or soft tissue edema in more than half the cases. The incidence of respiratory complications indicated an area of opportunity for the improvement of extubation protocols and respiratory tract management in special postoperative care units.

Finally, the decision to perform spinal fusions in elderly patients with multiple comorbidities must be carefully considered, given that adverse perioperative outcomes are much more probable in this type of patient.

All authors declare no potential conflict of interest related to this article. 
CONTRIBUTION OF THE AUTHORS: This study was prepared by 7 authors. Each author made significant individual contributions to this manuscript. AG, LN, and EM contributed to the concept and design of the study, as well as to the literature review. AL contributed mainly to the data collection effort. ATG performed the statistical analysis. AG, EM, TF, and MS were the main contributors to the writing and revision of the manuscript. JMPA provided methodological assistance to the preparation of the manuscript.

\section{REFERENCES}

1. Young WF. Cervical spondylotic myelopathy: a common cause of spinal cord dysfunction in older persons. Am Fam Physician. 2000;62(5):1064-73.

2. Vega-Pérez OE, Elizalde-Martínez E, Gómez-Espinosa LN. Incidencia de mielopatía espondilótica cervical en el periodo 2005-2009 [tesis]. postgrado para obtener La especialización médica en Ortopedia, registro R-2010-3401-23.2010.

3. Law MD Jr, Bernhardt M, White AA 3rd. Cervical spondylotic myelopathy: are view of surgical indications and decision making. Yale J Biol Med. 1993;66(3):165-77.

4. Kadaňka Z, Bednařik J, Novotný O, Urbánek I, Dušek L. Cervical spondyloticmyelopathy: conservative versus surgical treatment after 10 years. Eur Spine J. 2011;20(9):1533-8.

5. Gao R, Yang L, Chen H, Liu Y, Liang L, Yuan W. Long term results of anterior corpectomy and fusion for cervical spondylotic myelopathy. PLoS One. 2012:7(4):e34811.

6. Guarapana JG, Weinhold PJ. Discectomía cervical anterior com artrodesis íntersomática en patología discal y degenerativa. Disponível em: http://www.neurocirugia-venezuela. com/articulo01-01-07-08.pdf. Março 2017.

7. García-Armengol R, Colet-Esquerre S, Teixidor-Rodríguez P, Alamar-Abril M, Cladellas-Ponsa JM, Hostalot-Panisello C, et al. Anterior approach complications in cervical spinepathology. Neurocirugia (Astur). 2007;18(3):209-20;12.

8. Hoppenfeld S, de Boer P. Abordajes de cirugía ortopédica. 3a. ed. Madrid: Marban; 2005
9. Jain KK. Anterior approach to the cervical spine. Can Med Assoc J. 1974:111(1):49-50.

10. Sagi HC, Beutler W, Carroll E, Connolly PJ. Airway complications associated with surgery on the anterior cervical spine. Spine (Phila Pa 1976). 2002;27(9):949-53.

11. Rothman RH, Simeone FA. La columna. 4a. ed. Madrid: Elseiver; 2007.

12. Canale TS, Beaty JH. Campbell's cirugía ortopédica. 11a. ed. Madrid: Marban; 2012.

13. Palumbo MA, Aidlen JP, Daniels AH, Bianco A, Caiati JM. Airway compromise dueto laryngopharyngeal edema after anterior cervical spine surgery. J Clin Anesth. 2013;25(1):66-72.

14. Palumbo MA, Aidlen JP, Daniels AH, Thakur NA, Caiati J. Airway compromise due to wound hematoma following anterior cervical spine surgery. Open Orthop J.2012:6:108-13

15. Boakye M, Patil CG, Santarelli J, Ho C, Tian W, Lad SP. Cervical spondylotic myelopathy: complications and outcomes after spinal fusion. Neurosurgery. 2008;62(2):455-61.

16. González CV, Experiencia en el manejo de la Mielopatía Espondilótica Cervical en el Hospital General de México 2000-2006. Tesis de Posgrado México: DF; 2006.

17. Jae-Sung A, June-Kyu L, Bo-Kun K, Prognostic Factors That Affect the Surgical Outcome of the Laminoplasty in Cervical Spondylotic Myelopathy Clinics in Orthopedic Surgery 2010;2:98-10 